\author{
ハシボソガラスの自動車を利用したクルミ割り行動 \\ のバリエーション \\ 仁平 義 明 \\ 東北大学文学部心理学研究室
}

\title{
Variations of behaviour of Carrion Crows Corvus corone using automobiles as nutcrackers
}

\author{
Yoshiaki NiHeI \\ Department of Psychology, Faculty of Arts and Letters, \\ Tohoku University, Kawauchi, Sendai 980-77
}

\begin{abstract}
We investigated the curious behaviour of Carrion Crows Corvus corone that make use of automobiles to crack walnuts. A typical sequence of the behaviour is : a crow puts a walnut in front of the automobile that is stopped by a traffic signal ; then the car run over the walnut and the crow eats the fragements of the walnut. This behaviour was frequently seen during the 21 months of the observation period and 43 occurrences of these were recorded in detail. The behaviour is found to consist of several variables : the procedure to get walnuts, the state of walnuts, the way to set walnuts on the road, time of the day, places, whether there are other crows around, how long to wait before abandoning, whether the crow tries to change the position of the walnuts, and the way the crow eats the cracked walnuts. The analyses of these variables suggest that the carusing behaviour of the crows is not accidental but rather systematic. Crows sometimes drop walnuts from more than 10 meters above the ground to crack them but some walnuts are too hard to crack by this method. We suggest the car-using behaviour is an alternative invention to crack walnuts that are too hard, or walnuts covered with pulp. Taken together, we consider the car-using beheviour of Carrion Crows to be intentional behaviour.
\end{abstract}

Key Words : Carrion Crows, Learnig, Nutcracking behaviour, Walnuts, Automobiles.

ハシボソガラス Corvus corone などカラスがクルミを食べることはよく知られている (たとえば, MAPLE 1974, 唐沢 1988, 滝之入 1993 など). クルミは $1 \mathrm{~g}$ あたり $6.73 \mathrm{kcal}$ とカロリー価が高い食物であるが（四訂日本食品標準成分表 1982），オニグルミ Juglans mandshurica Maxim. var. sachalinensis などは核が堅いため, 嘴でつついただけでは 割れにくい，そこでカラスがとる方法の一つは,クルミをくわえて上空に飛び立ち，コン クリートなど硬い地面に投下して割る方法である. 同様な方法は貝類を食べるときにる使 われ，この「投下法」はカラスには広く観察される行動である（ZACH 1978，1979）。

カラスがクルミを割るすう一つの方法は，自動車にクルミをひかせて割り，子葉部分を 
食べる方法，すなわち「車利用法」である．カラスの車利用法らしい行動は，これまで2 例が報告されている（MAPLE 1974 ; GROBECKER \& PIETSCH 1978). MAPLE (1974) は，自分が自動車を運転中に観察した一例の行動が車利用法である可能性を最初に示唆し た. ただし，この例は，一羽のアメリカガラス Corvus brachyrhynchos が, 道路上にク ルミを上空から落として，その街路の上を飛んでいたのを目撃したという観察にすぎい． MAPLE はそのまま車で走り去ったので，クルミが車によってひかれたかどうかは確認さ れなかった。したがって, 報告例の論文タイトルは「カラスは木の実割りに自動車を利用 するか？」という疑問文になっている. それに対して, GROBECKER \& PIETSCH (1978) たちは,「カラスは木の害割りに自動車を利用する」というタイトルの論文で，自分たち が観察した一羽のカラスの行動が意図的な車利用行動であると断言した. 彼らは, カリフォ ルニアのロングビーチで, 一羽のアメリカガラスが, 約 $10 \mathrm{~m}$ の上空から一個の palm fruit Washingtonia sp. を道路上に落として，それが車にひかれるのを待ち，砕片をく わえさったこと, また, 20 分後同じような行動を再度繰り返したことを報告した. しかし， 彼らの観察もまだ不確定な要素を含んでいた。このケースの行動は, $10 \mathrm{~m}$ あの上空から実 を投下しており，通常の投下法を意図した可能性を必ずしあ排除できないからである.

車利用行動が意図的な行動として存在することは, ハシボソガラス Corvus corone に ついて, 仙台市の東北大学川内キャンパス近辺における観察により示晙された（仁平 1992)、ハシボソガラスが信号待ちで停車した自動車の車輪の前にクルミを置き，車にひ かせ, 食べる行動が頻繁に観察されたのである.

さて,この車利用法は, 行動形態から考えて基本的に学習性の行動であることには疑い なく, ハシボソガラスの学習性の行動変容を考える上で情報価の高い行動である. しかし, 車利用行動は多くの变数から構成される变異の多い行動である. たとえば, クルミをひか せるのにそれを道路上にセットする「セッティング法」という変数をとりあげても, 信号 待ちで停車した車の車輪の前に置く，あるいは車がひきそうな道路上の位置にあらかじめ 置く, という変異が存在した（仁平 1992）。したがって,この行動を研究するためには, まず行動の多数の変数について, その変異の範囲を確定する必要がある。そこで, 本論文 では, 車利用行動の变異の範囲を明らかにすることを目的として, 長期間の観察の結果に ついて報告する。

方法

\section{1）観察対象地}

観察は仙台市川内の東北大学キャンパス近辺で行なった（Fig．1)、対象地は筆者自身 が勤務するキャンパスで, カラスの車利用行動を偶然に見る機会が多く，車利用行動がみ られたいくつかの地点は通勤路にああたっていた. 川内キャンパスは, 広瀬川に囲まれた 旧仙台城 (青葉城) 二の丸および三の丸跡で, 周囲には沢が多く, オニグルミが多数自生 している，それゆえキ+ンパス各所（特に図書館脇，教養部生協前広場，附属植物園入り 口など）では，カラスによるクルミの投下が頻繁に観察される. Fig.1のAからHまでの ポイントの道路脇には例外なくオニグルミが存在している.

また，対象地を通る道路は，すぐに市街のメインストリートに直結していて，市街地よ 


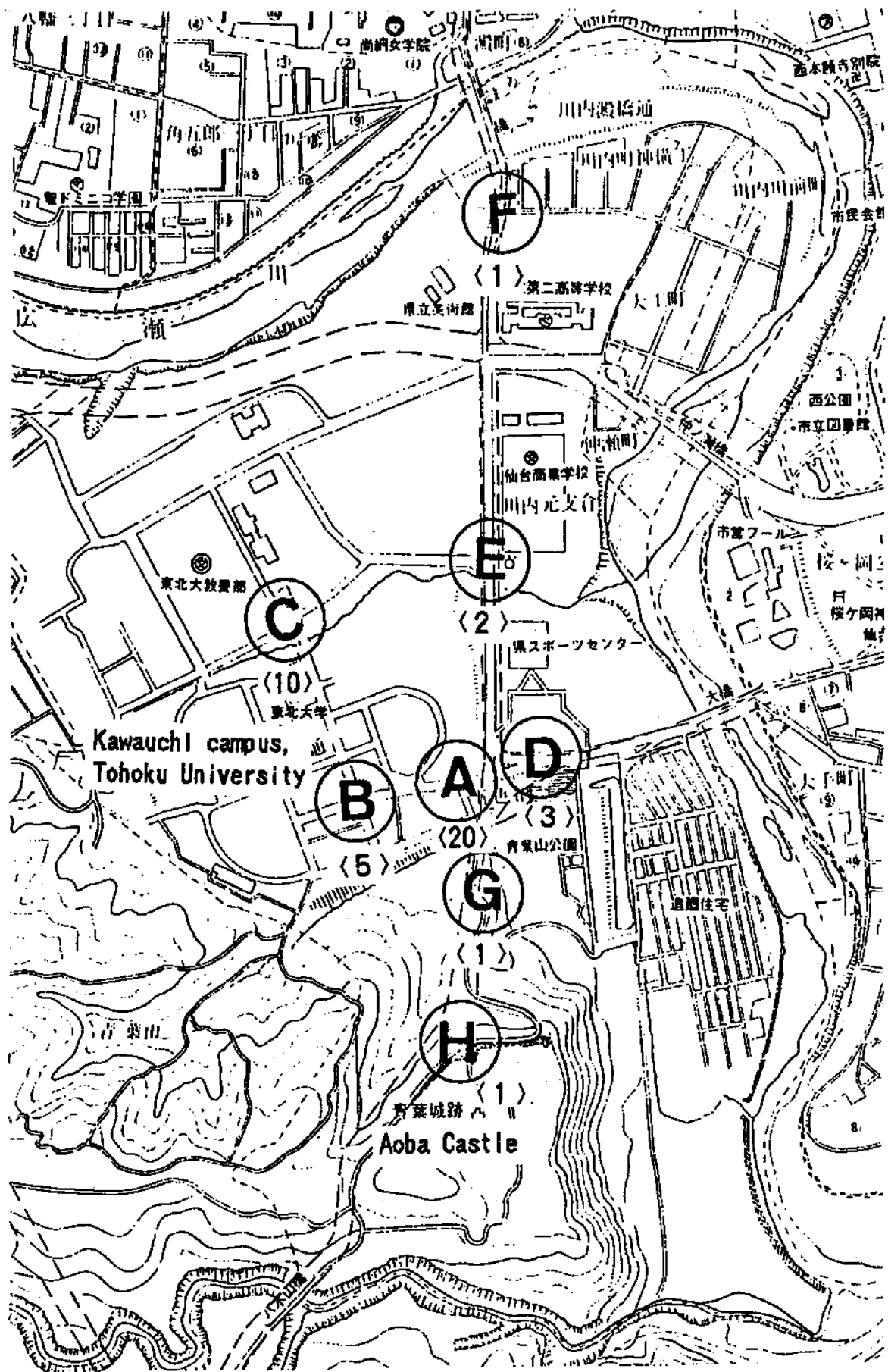

Fig. 1. Places where behaviour of Carrion Crows using automobiles as nutcrackers was observed $(A \sim H)$. Each number below the circled place indicates the number of obsevations there. 
りは少ないけれど適度な交通量がある.さらに，この近边は広瀬川の河岸段丘や丘陵地で あるため, 車が徐行したり停止したりする必要がある急な坂や急カーブあ多く, また交差 点も存在する (Fig. 1 参照).

2）観察期間と方法

観察期間は, 1992 年 2 月から 1993 年 11 月までの約 1 年 9 か月間である.この間に，(1) 筆者自身が前に行動を見かけたり，あるいは学生や学内関係者などから同様な行動を見か けたという情報を得たことのある地点で待ち, 待っている間に車利用行動が生起すればそ れを観察する，(2)観察地点のどこかでカラスが車利用行動を開始しているのを筆者が偶 然に発見したとき，そのまま観察を続ける，のいずれかで観察を行なった．車利用行動は， 地点の数む多く, 時刻も一定ではない. そのため, あらかじめポイントを設定し待ち受け て観察をしょうとしても空振りになる場合が多かった. 得られた観察例は，カラスが車利 用行動をすでにスタートしているのを偶然見かけたときから記録を開始したケース（2) が主であった．記録した観察例は，合計 43 例であった。ただし，車利用行動を見かけても 特に記録しなかったケースもこの同数程度あった．また，肉眼による観察の他に，可能な 場合にはVTR 撮影, 写真撮影をあわせて行なった.

3）行動の変異の変数

車利用行動は多くの可変な要素 (変数) をあつ変異の多い行動であった. その変数になっ ているのは次のような行動の要素であった : (1)くクルミの性質と調達法>ーどのような 性質のクルミ（花肉のついたもの，あるいは核果だけのもの）を, どのようにして調達す るか, (2)<時刻・場所・機会>一車利用行動をするのに, どのような時刻, 交通量の, ど のような場所で行うのか, また, 行動の開始の機会として他の個体が近くに存在するとき が選ばれるか，(3)くセッティング方法〉一どのようにクルミを道路にセットするか, (4) 〈待ち行動打ち切りの臨界時間〉一路上にクルミを置いてひかれるのを待つのに, どのく らいの時間を超えたら待ち行動を打ち切るか, (5)<置き直し行動〉一もし, 車がクルミを かすめてはねたりしてクルミが適当な位置からずれたとき，置き直しをするか，(6)<他 個体への対応>一待ち行動途中で他の個体があらわれたとき, どう対応するか，(7)<食行 動>一どのようにクルミを食べるか，である．

以上のような観点から車利用行動の分析を行なった。

\section{䊅果}

筆者が最初に車利用行動を観察したのは，1992 年 2 月 15 日午前 9 時過ぎ，青葉城跡入 り口（東北大学川内キャンパス入り口でもある）隅櫓脇の交差点であった（Fig. 1 のA地 点).このとき,一羽のハシボソガラスがくわえていたクルミを，たまたま信号待ちで停車 した筆者自身が運転するセダンタイプの乗用車の直前に置いて道路脇に退き，車にクルミ をひかせようとする行動が観察された（Fig. 2-a〜eの写真の行動参照. ただし, Fig. 2 の 写真は, A地点, 1992.11.13. 撮影). また, 路上にクルミを置き, 車にひかれるのを待ち, うまく車にひかれたクルミを食べるまでの一連の行動が最初にビデオ撮影されたのは, 同 2 月 19 日午前 9 時ごろであった. 最初の観察以来記録を行なった 43 例から明らかにされ たのは, 以下の通りである. 


\section{1）地点と時期}

車利用行動 43 例が観察されたボイントはFig. 1 の地図に示した通りである.なお地図 のポイント A〜Hの下には観察回数を数字で示した. ただし, 観察回数が 1 回になってい る場所 (F, G, H) です, 記録はしなかったがそれ以外にす車利用行動を必ず見かけた から，どの場所でも車利用行動は複数回みられた．とくにA付近は車利用行動が最も頻繁 に観察された場所で, 43 回中 20 回を占めていた. ただし，観察者自身の行動範囲による バイアスがあるので,これがそのまま場所ごとの行動の頻度を正しく反映しているかどう かは今後検討をする必要がある．時期・時刻等の要因についてあ同様である.

車利用行動 43 例は，すべてハシボソガラスについて観察された．そのうち VTR 記録を した 1 例では，ハシボソガラスがセットして車が割ったクルミをハシブトガラスが途中か ら割り込んで食べる横取り行動がみられた（A地点, 1992.2.19.).しかし，ハシブトガラ ス自身による車利用行動は 1 例す観察されなかった. この地域は, 日中, 多数のハシボソ ガラスとハシブトガラスが混在して見かけられることを考慮すると, 車利用行動はハシボ ソガラスに特殊化された行動だといえる.

時期については，偶発的な観察が主であり，観察者の都合による観察むらがあったので， 実際の月別頻度を反映するあのではないが, 観察例数の月別分布は次のようになっていた (カッコ内は観察例数)，1992 年 2 月（4），7月（1），8月（10），9月（4），10月（3）, 11 月（4)，12月（2）, 1993年 1 月（3）, 2月（5)，7月（1）, 9月 (5)，11月 (1). 1993 年 8 月に観察例がなかったのは，一つには記録的冷夏のためクルミが実るのが達かっ たためと考えられる.なお，同年 10 月の観察例が皆無であるのは観察者が不在と多仙に より記録をしなかったためである.しかし，割れたクルミの痕跡などから推測すると，少 なくとす 8 月後半から 2 月までの間は，すし組織的かつ広範囲にわたる終日観察をすれば, 車利用行動が月内のいずれかの日には必ず起こっていることを確認できると思われる.

（注 : 脱稿後，1994 年には，4月と5月にあ観察された.)

車利用行動の時期は，記録した観察例数と，記録しなかったケースを含めたふだんの印 象からすると、クルミが熟す 8 月末から9月初にかけてが最す頻度が高い、記録した 43 例中 17 例が 8 月と 9 月に観察されたあのである、この時期のカラスがクルミを採取する 方法には，さまざまな形態があり（後述），カラスは容易にクルミを調達できる．また春か ら夏にかけては車利用行動はあまり観察されなかった,一つには, カラスが埋めて眝蔵し ておいたクルミを取り出して使用するのに時期が革くなると発牙して使用不能になるため か，あるいは，他のかたちの採食が容易な時期であるためかむしれない．それに加えて， 春から夏にかけては，木にあるクルミの子葉部分はまだ肥厚していないという理由るある. 7 月に, クルミを道路にセットして待っているカラスを発見し，そのクルミを採取し割っ てみたが，ほとんど可食部分のない未熟な実であった（C地点, 1993.7.24.). 時期からいっ て, 無駄な行動をしていたケースであった.

2）行動のバリエーションと変数

すでに述べたように, 車利用行動は多くの可変な要素（变数）をもつバリエーションの 多い行動であった. 車利用行動はこ㣗らの変数を考慮して行なわれており，それぞれの変 数が多様なかたちをとりうる. 以下，それぞれの変異の範囲について，順次述べていくこ とにしたい. 
（1）クルミの特性，および調達法

投下法がもっとも頻繁に行なわれる東北大学川内図書館脇で 1992 年から 1993 年にかけ て割れたクルミの核片 51 片を採取したが, それらは形態上の変異はあるすののすべてオ ニグルミであった．またカラスが車利用行動で路上にセットしたクルミを採取した 3 個の 例む，同様にすべてオニグルミであった.

車利用行動で使用されるクルミは，(1)核果だけの場合（35 例）と，(2) 花肉のついた青 クルミの場合（ 9 例）の二通りであった. 当然ながら, 青クルミの使用は, 7 月 ( 2 例), 8 月（ 4 例)，9月（ 3 例）に限られていた。この時期には，核果だけとはいっても花肉の はがれたばかりの表面の湿ったクルミの使用るあった.このうち8月下旬から9月下何ま では, A地点やB地点に青クルミのつぶれた跡が毎日のように残っていた。

そのクルミをカラスが調達する方法は, (1) 落果した青クルミを樹下から拾ってそのま ま使用する，(2)木から青クルミを直接採取する，(3)埋めて眝蔵してあった核果だけのク ルミを使用するという形態があることが確認された. 8 月，9月は, 風雨等によって落果 するクルミが数多くあり，それらを拾って車利用法にすぐさま使用するケースもあった. 枝になっているクルミを直接くわえさる行動（BおよびC地点脇の木で 1992.8.30.に計 2 回)，あるいはそれをすぐさま車のルートにセットする行動（A地点脇の木で 1993.9.21.） る観察された，また，なっている実を木から道路に值接落としたケースす 1 例観察された (C地点, 1992.9.3.). それ以外は, 埋めて眝蔵してあったクルミを取り出して使用するこ とが多いと思われる. 実際, クルミの樹下ではない場可からクルミを掘り出して使用した ケース（A地点, 1992.8.25., 1992.11.26.) や，いったん道路にセットして長時間待っても 成功せず, クルミを草むらの中に埋めこんで檃し去るケース（A地点, 1992.10.3.) が観 察された. ただし, 待ち行動がすでにスタートしている段階で観察を開始したケースが多 いため, 各調達法の頻度分布は明確ではない。

(2) クルミのセッティング方法

車にひかせるためにクルミを路上にどうセットするかには, 次のようないくつかの形態 があった (Table. 1 参照).

(A)一(1)<直前置き>

「クルミを割る一車輪」という目的一手段関係の心理的距離があっとも近い行動は，信 号待ちで停車した自動車の車輪の前にクルミをくわえていって置く方法であった(「直前 置き」, Fig. 2 の行動).

(A)一(2)<強引固き>

その亜型（1 例）には, 発進してまだ徐行中の車の前に強引に出ていって車を止め，そ の前に置くという方法がみられた（A地点, 1992.11.13.)。これは「強引置き」とであ表 現できるだろう。この1例の場合,このセッティング法でうまくいかず，さらに少し移動 して, 直前置きに切り替えクルミ割りに成功した。

(A)一(3)<直前投げ>

また別な亜型（1 例）には，信号近くで徐行している車の車輪へ向けて，くわえている クルミを道路脇加ら投げつける行動もあった（A地点, 1992.10.2.).これは「直前なげ」 と表現してよいだろう。この直前なげの 1 例は, 次に述べるルート置きをしばらく続けて いた後，クルミをくわえて直前なげに切り替えたケースであった.（なお, Table. 1 のセッ 
Table 1. Variations of the beheviour of Carrion Crows in setting walnuts on the road to use automobiles as nutcrackers.

How to set walnuts

Number of observations

(A) Setting in front of an automobile

(1) Direct setting

Put a walnut directly in front of an automobile stopping at traffic signals.

(2) Compulsive stopping ;

Stop a slowly moving automobile by walking in front of the automobile, and put a walnut in front of the wheel.

(3) Direct throwing;

Throw a walnut from its beak directly in front of a wheel of an automobile moving slowly.

(B) Setting in the path of cars

(1) Put a nut in the direct path;

Put a walnut in the direct path of cars where cars are likely to run over it.

(2) Meaningless imitation of behaviour of other crows ;

Put a walnut on the road where cars are unlikely to run over it.

(3) Multiple setting in the path;

Put a few walnuts in the path of cars.

ティング法ごとの観察回数は，以上の 2 例については，セッティング法を別々にカウント している).

(B)一(1)<ルート置き>

別なタイプには，車が通っていないときに道路上の車が通りそうな場所にくわえてきた クルミを㯰き，道路脇などで待つ方法がみられた（「ルート置き」）、ルート置きには，道路 上の電線にクルミをくわえてとまり，路上に落とすかたちでセットする場合す含まれる． これが投下法ではなく，ルート置きであると考えた方がよい理由には，いくつかの理由が ある、第一は, 通常の投下法のように, 落としたすのを追って降下し確認する行動がまっ たくみられないこと．第二には，電線からの投下といっても，投下によってクルミが割れ たケースは一例す観察されなかったこと、第三には，花肉がはがれたばかりの乾嬠してい ない割れにくいクルミが使用される場合があったことである.

(B) 一(2)<非本質的な模做 $>$

ルート置きの亜型には，とまった電線から投下した結果，まったく車がひきそうすない 見当䧺いのところにクルミがころがってあ，そのまま位㯰を補正しないで，長時間待ちつ づけるケースも2例あった（C地点, 1992.8.26. ; C地点, 1992.8.30.).この場合,「車が ひきそうな位置にクルミをセットする」という車利用行動の本質部分を理解せずに，交差 点のどこかにクルミを置くという表面的な部分だけを模做している可能性が高い．これは 「非本質的単純模做」と呼ぶべきであろう.ただし，これが学習途上の形態であることを 確認するためには，個体識別による追跡研究を行なう必要がある.

(B) 一(3)<複数置き>

さらに,ルート置きの別な亜型には，1 カ所の交差点にすでに 2 個置いてあるクルミに 


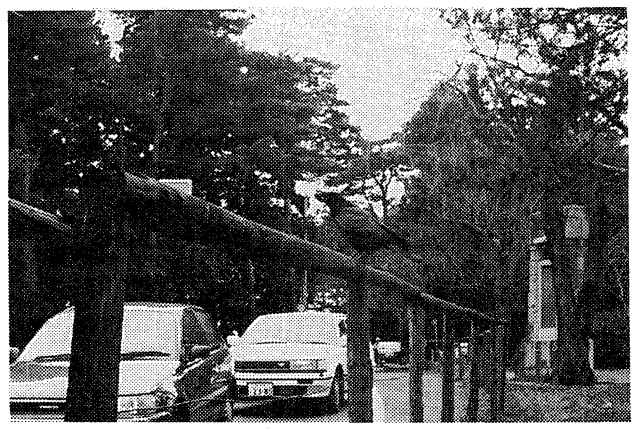

a

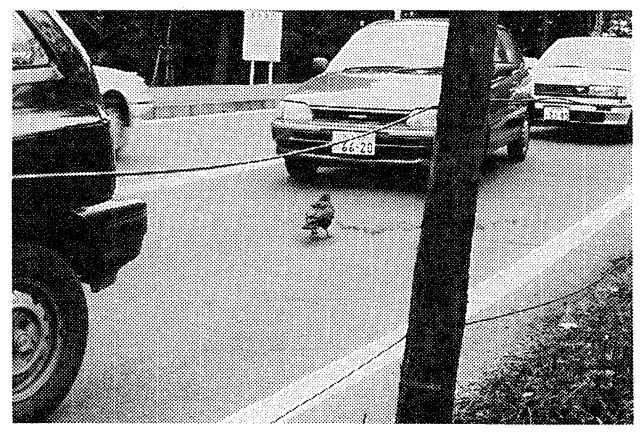

$\mathrm{b}$

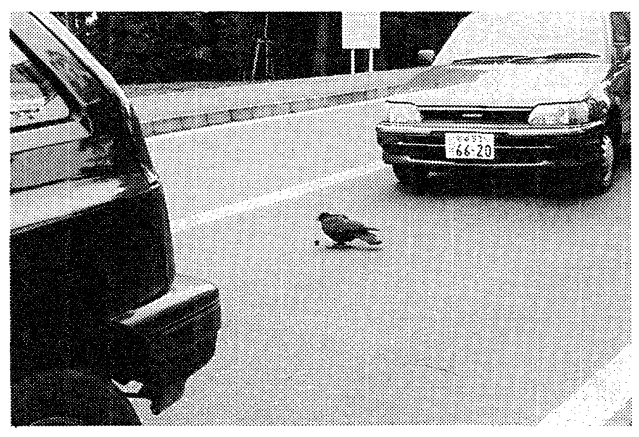

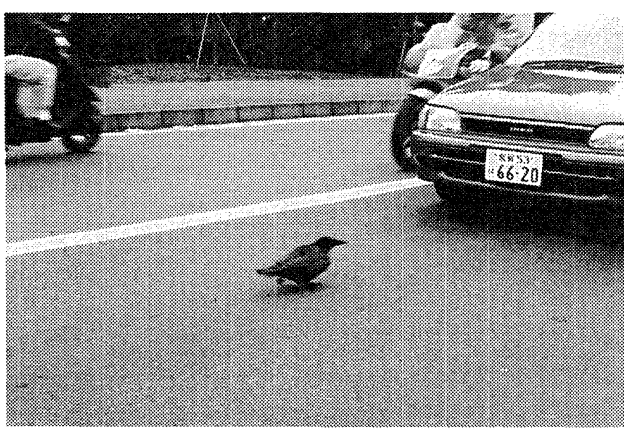

$\mathrm{d}$

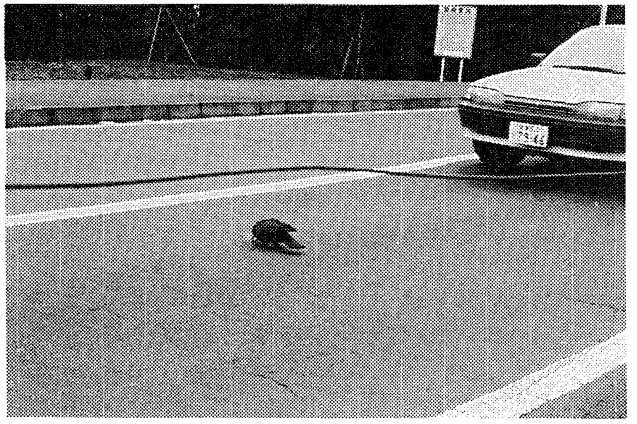

e

Fig. 2. A carrion crow Corvus corone, (a) waiting for automobiles to stop by traffic signals with a walnut in its beak on a fence, (b) approaching an automobile, (c) putting the walnut in front of the wheel of the automobile, (d) getting out of the way to wait for the automobile to run over the nut, (e) eating fragments of the nut run over by the automobile.

加えて, 3 個目のクルミを直接木から採取してきて置く行動,「複数置き」も 1 例観察さ れた（A地点, 1993.9.21.).この時は，まだ木に実がありクルミを得やすい時期であった. この例の場合, クルミ割りをさらに効率的に達成するために, 個数という新しい変数を導 入したとみることあ可能かむしれない. $Z_{\mathrm{ACH}}$ (1978）む，巻き貝の投下法をとるカラス が，まれに同時に 2 個の貝を投下することがあると報告している. 
行動の観察は, すでに路上にクルミが置かれていて, カラスが電線上や路傍で待ってい るのを目撃してからスタートした場合が多かった，その場合，はじめからルート置き行動 だったのか，それとも直前置きをした車がうまくひいてくれず, 別な車にひかれるのを待っ ていたところかは断定しにくい.しかし，これを待ち行動になる可能性の高い「ルート置 き」としてカウントした場合，七ッティング方法の例数は，直前置きとその覀型（直前投 げ, 強引置き）が 14 例, ルート置きとその亜型（複数置き, 非本質的模做）が31例であっ た.

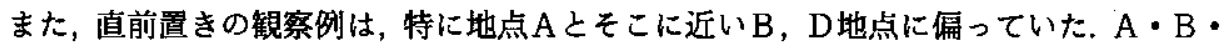
D地点で観察されたセッティング方法は, 「直前置き」プラスその亜型が 14 例, 「ルート 置き」が17例なのに対して，それ以外の地点 (CEFG H) の合計は, ルート置きとそ の亜型の非本質的模做のみ 14 例であった，A地点は交通量が比较的多く，信号で車が停 車する機会が多いためか, あるいは特定の個体が $\mathrm{A}$ 地点の近辺で活動しているためか, そ の连いの理由は不明である.

（3）時刻・場所・機会の選定

車利用行動の行なわれる地点には，いくつかの共通な条件が存在していた，第一は，交 差点やその近傍 (A, C , E , F)，急な坂でしかも急なカーブ $(\mathrm{G}, \mathrm{H})$, ロータリーになっ ていて横断歩道すある（B）など, 車が停車したり，かなりの徐行をしたりする場所であ る. 第二は，交通量が適度にあることである. 交通量が少なすぎてもチャンスは少ないし， 逆に車が途切れなく通れば，クルミをセットしたりひかれたクルミを食べるチャンスもな いことになる．第三は，例外なくクルミの木が数メートルと離れないごく近くに存在する ことである.たとえば，車利用行動の頻度が最も高かった青葉城隅櫓脇交差点（地点A） は交差点脇にクルミの木が張り出している.

車利用行動は, 午前 7 時台から午後 5 時台まで, どの時間帯についてす観察された。 た だし，観察例は，午前 8 時台と 9 時台が 43 例中 23 例を占めている. 観察者の行動時刻に あバイアスがあり，確実な時刻分布を知るためには，終日の広い範囲の観察が必要になる だろう.しかし，これらの場所での交通量などを考えると，今回の結果はそれほど実際の 時刻分布とかけ離れていないと思われる.

また，他の個体が存在するのにカラスが車利用行動を開始するのを目撃したケースは皆 無であった.

（4）待ち行動とあきらめ時間

クルミを車の通りそうなルート上にセットしても，すぐに車がひくとは限らない．カラ スはこのような場合，しばらく待つことになる.しかし，この待ち行動には時間というコ ストがかかる，他の採食が可能なはずの時間を待ち行動にさくという時間的コストが報㯺 を上回るとき，カラスは待ち行動を打ち切ると仮定される．あきらめが起こる待ち行動の 臨界時間はどのくらいになるのだろうか.

最初にビデオ記録をしたルート置き行動では，クルミがセットされてからうまくひかれ るまでカラスの待っていた時間は 6 分強であった（A地点, 1992.2.19.). ルート置きをし ていて,クルミがひかれないためにカラスが待ち行動を打ち切るまで観察を続けたケース は 3 例あった. それぞれ，あきらめ時間は，33 分，25分，25分であった（それぞれ，C地 点, 1992.8.26. ; C 地点, 1992.9.18. ; A 地点, 1992.10.3.) 逆に, クルミがうまくひかれた 
例のうちで最す長時間待ったケースでは, 待ち時間は 35 分であった (C地点, 1992.8.25.) . しかし，この 4 例すべて, ルート置きの待ち行動を発見してから観察をスタートしたケー スだった，それゆえ，正確なあきらめ時間の範囲についてはさらに検討を要するが，あき らめ時間は 35 分程度を超える時間であろうことは推測できる。

(5) 置き直し行動

クルミを道路にくわえ落としても，うまく車輪がひきそうなルート上からはずれてしま うことがある.また，せっかく良さそうな位置にセットしたクルミでも車輪がかすめ，道 路脇にはねとばされてしまうことがあった。このようなとき，ずれたクルミを道路上の適 当な場所に置き直す行動がみられる，ときには，二度目，三度目と置き直す場合すあった (A地点, 1993.10.3.).したがって，クルミを置くべき場所は道路上で車輪が通過するとこ ろという条件を理解しているカラスも抢り,クルミがその条件からはずれたとき, 㯰き直 しを行うことがあると考えられる.

（6）他個体への対応

他の個体が存在するときに車利用行動を開始する例は目撃されなかったが，カラスがク ルミをセットした後, 他の個体がそのカラスの近くに出現したことが4例あった．そのう ち 1 例では, カラスは道路の反対側までクルミをくわえて移動し，「直前投げ」をする行 動をとった（A地点, 1993.10.3.). 別な 1 例は, 他個体がそばにくるとすぐにクルミをく わえて飛び去ってしまった（D地点, 1994.2.24.).

また, 別な 2 例では, 待ち行動中のカラスは,クルミを残し, 同じ電線にとまった他個 体の目前を飛び去った．ほどなく，後から出現した個体も飛び去っていた（C地点, 1992. 8.25. ; C地点, 1993.2.21.). 筆者は，その 2 回とも; 残されたクルミを值ちに除去したが, 除去後むその場に留まっていると, 先のカラスと推定されるカラスが戻ってきて,クルミ があったはずの地上をうろうろと梊しまわる行動をとった．したがって，いったん飛び去っ た行動は, 自分が他個体の目の前を飛び去ることで他の個体を誘導して去らせ, 自分だけ その場にもどる「フェイント行動」であった可能性が考えられる．前に述べた例のような 横取り行動を防ごうとすれば，ハシボソガラスにはなんらかの対処行動が必要になるから である.

（7）食行動

カラスはひかれたクルミを食べるとき，ふつう後から車が来なければその場で食べるこ とが多かった．車がそこに来ると破片をくわえて，道路脇に退いて食べることもある．し 功，碎片は散在するため一度にくわえきれず，車が来ても退かず，そのまま停止してい る車の前で平然と食べ続けたり（Fig. 2-e)，車がクラクションを鳴らしてあ食べ続けるこ とああった. そのような場合, 車はやがて徐行して進みカラスを無理やり退かすことにな る.また, 中には急発進して，カラスがあわてて退く場合ああった．車利用行動は，危険 というコストを含んでいるのである.

1）車利用行動の学習

（1）車利用行動の成立 
偶発的な観察を主とした分析であったが，そこからは車利用行動のおよその輪郭を把握 することができた．ハシボソガラスの車利用行動は「多くの可変な要素から構成されるバ リエーションの大きな行動」であることが確認された，また，同一個体であ「強引置き」 でひかせるのに成功しないと，別な場に移動して「直前置き」に移行するケースや，「ルー ト置き」で成功しないと「直前投げ」に移行するケースなど，一個体中での方法の柔軟な 使い分けがあることが確認された．こうした複雑かつ柔軟な行動の学習の成立をどう考え， 行動のバリェーションをどう記述したらよいのだろうか.

まず, 車利用行動はどのようにして成立したのだろうか?

車利用行動がみられたすべての地点に共通していたのは，道路上にクルミの枝が張り出 していたり，少なくとるその数メートル以内にクルミの木があったりすることである．た とえば，車利用行動が最もしばしばみられた地点Aも，クルミの枝が交差点近くに張り出 している.このような場所では，カラスは，道路に落下したクルミが偶然車にひかれると ころを見るか，あるいは車にひ加れたクミを見る機会は十分あったと考えられる．カラ スがこのような経験をしたとき，新たな目的一手段（クルミを割る一車にひかせる）関係 の洞察を通じて車利用行動を発見するに到ったのは自然な経過であると思われる。すちろ ん，その目擊経験が自己の車利用行動につながるには，それを媒介するすのとして手段一 目的関係（車一クルミを割る）を洞察できる能力が介在しなければならない.

（2）車利用行動の伀播

さらに，車利用行動はすべて独立に成立したのではなく，一個体の行動が複数の個体に 伝播した可能性が考えられる（スタートにある個体は独立な複数の個体ですよい）。この 伝播の部分は, 学習の分類でいえば、最初の個体の学習が木から落ちたクルミが車にひか れる目撃経験から成立した洞察学習であるのとは巽なり，他の個体の車利用行動が最終的 にひかれたクルミを食べるという強化を受けるのを見た「代理強化」による観察学習であ

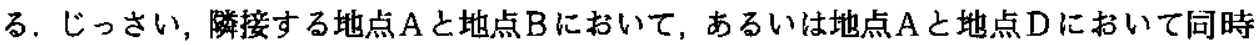
に別な個体がルート置きをしていることがあった。また，值前置きなどきわめて効率的に 車利用をするカラスがいる一方で，クルミを車がひきそうな場所にセットするという行動 の本質を理解しないで，単なる模做行動をするカラスも存在していた（注：少なくともこ れらのケースが別の個体であることは，胸部の羽毛の特殊な抜け方から識別できた)。こ れらの事実から，複数のハシボソガラスが車利用行動を行なっていることは確認できる． しかし, 車利用行動をするハシボソガラスの数がどのくらいになっているかは, 今後の個 体識別に基づく研究を待たなりればならないだろう，しかも，他個体が存在しないときに 車利用行動が開始される傾向は，観察学習による行動の伝播にとってマイナス条件になる はずである．この点についても，今後の検討が必要であろう。

車利用行動の広がりについては, 調查対象地（仙台市川内）以外の地域の広範囲な調 查 あ必要であろう. 未確認ではあるが, 山形県（西牧光子, 私信), 岩手県 (川口裕基, 私信) であ，同様な行動を見かけたという筆者への通報があった．仙台市川内の東北大学キャン パス付近は，この行動を観察するには好適なフィールドではあるが，すでに述べたような 条件が整っておりさえすれば車利用行動は他の土地であ観察されると思われる.

(3) 車利用行動の内容の変容

車利用行動は，投下法とは別のルートからクルミを割るというゴールにいたる行動であっ 
た.それはまた,クルミの特性と調達法, 道路へのセッティング方法, 時刻・場所・機会, 置き直し行動, 待ち行動, 他個体人の対応, 食行動など, 多くの変数を含む行動であった. 個体間でも個体内です，行動のバリエーションは大きい，一つのセッティング法がうまく いかないと，次に別なセッティング法をとるなど，一個体内で柔軟な行動の使い分けがみ られた例もあった. 車利用行動の成立と伝播の部分は, それぞれ洞察学習や観察学習とし て性格づけることが可能であろう.しかし, 洞察学習や観察学習の結果生じた行動の各変 数の内容が, その後の試行経験に伴ってどう変化したかを位置づけるためには, 車利用行 動が数多くの变数を含む複雑な行動であるがゆえに，別な理論的枠組みが必要になるかる しれない，その一つの候補として考えられるのが, RUMELHART や NORMAN らが提唱 した学習への認知心理学的アプローチである（RUMELHART \& NORMAN 1978 ; NORMAN 1982). 彼らは, 複雑な知識構造や複雑な行動パターンの学習は,「スキーマ （schema）を形成する」ことにほかならないと考えた．スキーマというのは,「多くの変数 から構成される概図的な知識構造体」であって,「それに基づいて認識や行動が行なわれ る枠組み」である，さらに彼らは，(1) 行動の枠組みであるスキーマ目体の学習（スキーマ 形成), (2)いったんスキーマを形成した後の各変数の制限や拡大あるいは最適化によるス キーマの効率化（チューニング），(3) スキーマに基づいた一回一回の行動の結果の蓄積 （デー夕蓄積），この三種の学習を区別している.スキーマ理論にしたがえば，たとえば， 車利用行動自体の成立は新たなスキーマの形成であり，一個だけのクルミではなく複数の クルミを置くようになる変数の変化はスキーマの効率化 (チューニング) であると位置づ けることができるかもしれない.

このような考え方は，車利用行動にとどまらず，投下法や，他種の鳥にみられる変数の 多い行動の学習（たとえば，ササゴイ Ardeola striata の投げ眲漁 (HiguCHI 1986, 1988)、ブッポウソウ Eurystomus orientalis による碾き臼としてのプルリングの使用 (NAKAMURA \& TABATA 1988 ; 中村・田畑 1990), 花以外の蜜を吸うメジロ Zosterops japonica の行動（上出・長野 1991 ; 上田 1991)）についてす, 学習の結果何が変化した かを記述するのに適用できる可能性があると考えられる．投下法も，「投下物の特性」,「投 下高度」,「投下場所」,「地面の硬度」等，いくつかの変数を含む行動である。また，たと えば，ササゴイの投げ慨漁は「投げる䁒の種類と特性」「待ちの場㫹と姿勢」「待ち時間」, 「対象となる魚」「投げる位置とタイミング」など多くの変数から構成される複雑な行動 である (HIGUCHI 1986, 1988):

しかし，本論文での観察は車利用行動全体のバリェーションを提示しただけで，一個体 内で車利用行動がどのように成立し，その後どのように効率化されてゆくかを論じるだけ の資料はない，したがって，鳥類の学習性の行動変容の内容にスキーマ理論を適用する意 味については,ここでは可能性を示唆するにとどめ,さらに組織的な観察を重ねた後, 稿 をあらためて論じることにしたい．

2）ハシボソガラスにとっての車利用行動の意味

既知のように，ハシボソガラスがクルミを摄食するのには投下法が可能である．観察地 近辺であ投下はさかんに行なわれている．投下法では，クルミを割るのに数回の投下が必 要な場合むあるが, それでも，ときには30分以上の待ち時間になるルート置きに比べれば, はるかに時間的コストの小さな行動である，（ただし，飛翔によるエネルギー消費のコス 
トもある、コスト比較には，具体的にオニグルミについて投下高度とクルミ割りの成功率 の綿密な検討もされなければならない，それでも，他の採食行動にさくべき時間の消費之 いうコストと飛行コストという質の異なるコスト間の直接比較は難しいかもしれない). また，直前㯰きにしても，発進した車にぶつかるかもしれない危険を冒すというコストが ある. ハシボソガラスはなぜ車利用行動を行なうのだろうか.

まず考えられるのは，この行動はカラスにとって「遊び」の意味を含んでいるという可 能性である.じっさいハシボソガラスが遊びを好むことはしばしば強調される（唐沢 1988 など). しかし，カラスが比較的長時間待ち続けることが少なからずあった事実や， 雪の中 (1993.2.24.) であ，強い雨の中 (1992.10.9.ほか) でもこの行動がみられた事実 は,やはり車利用行動はカラスにとって, 遊び成分以上に切実な摂食行動の成分が大きい ことを示唆している.

そこで，考えられるのは，車利用法は，「投下法では処理できないクルミを食べるため の方法」だという仮説である.8月末になると、クルミはだんだん熟してくるすのの花肉 に被われた核果は投下法では割ることはできない，それを即座に食べるために可能なのが， 車利用法である．また花肉がはがれたばかりの核果す乾燥度が低ければ，投下法では割れ にくいことになる.さらに，地中に埋めておいたクルミす，湿っていれば投下法では割り 難い場合があるかすしれない，積雪時も，雪がクッションになり投下法ではクルミは割れ ない.

それらすべてを解決する方法になるのが車利用法である．こう考えることで，なぜ車利 用法をカラスがとるのかが説明可能になる．投下法では割れない青クルミを使った車利用 行動が 8 月末から 9 月にかけて頻繁にみかけられることは, この可能性を示唆している. しかしこの仮説を検証するためには，車利用法で使用されたクルミと投下法で使用された クルミの特性の差異を明らかにする必要があるだろう. 投下法と車利用法がどう使い分け られるかは，なんらかの実験的な方法や，さらに組織的な観察によって解明しなければな らない問題として残されているのである.

また，なぜ車利用行動がハシボソガラスに特殊化された行動なのかという問題も未解決 である.おちらく，オニグルミがハシボソガラスの食眲レパートリーに最初に加わったの は投下法によってであったと推測される.投下法では，1回の投下でクルミが割れるとは 限らず，数回の投下の後に割れることが珍しくない，その場合，カラスはクルミをくわえ て上昇し落下するクルミを追跡下降することを数回繰り返す．こまめな飛翔の反復が必要 なら，クルミから得られるエネルギーから飛翔反復による消費エネルギーを引いた残差が 大きいほど，この行動のるたらす利益は大きい， Z crows）の巻き貝の投下法をカナタの Mandarte 島で観察した際，よその土地では投下 法に使用されるムール貝がこの島に存在するにあかかわらず，この島では投下法に使用さ れないことを報告した，彼は，Mandarte 島のムール貝は小さすぎて投下法をとる利益が 少ないからだろうと推論している，さて，この投下法の利益は，カラスの体重が少ない （飛朔による消費エネルギーが少ない）場合る大きくなる．したがって，投下法は，ハシブ トガラスに比べて体が小さめのハシボソガラスにとって, より利益の大きな行動であるか もしれない(ハシボソガラスとハシブトガラスの翼長差は成鳥で約 $10 \sim 20 \mathrm{~mm}$, 尾長差 約 30 35 mm; 内田 1969, 小林 1983). それゆえ投下法によってクルミが食慨対象にな 
りやすかったハシボソガラスで, 投下法で割れにくいクルミを処理するために車利用行動 が生まれたと考えれば，車利用行動がハシボソガラスに特殊化されていることも一応はう なづける．しかし，これも今後検証されるべき推測である. ハシブトガラスはクルミを食 べないわけではない，現に，ハシボソガラスが道路にセットして車がひいたクルミの横取 りをハシブトガラスが行なっている(結果参照).

3）フェイント行動

車利用行動には，なお確定の必要な興味深い行動あある. たとえば，クルミを確保する ために他の個体をあざむくフェイント行動の問題である.

これときわめて類似した行動が，チンパンジーについて報告されている（GoODALL 1971；1986).このケースでは, チンパンジーは, チンパンジー保菱区の期場で隠された抯 を独り占めするために，飰場から他のチンパンジーの前を別な場所に向かって歩いていき， ほかのチンパンジーを自分の後について移動させ，10 分後に自分だけ㽠場にとって返し， 餌のバナナを手に入れる行動をとった. チンパンジーが䬣を入手するために他の個体をあ ざむく行動をとることは松沢（1991）あ報告している.八シボソガラスでみられた 2 例の 行動は, 現象としてはチンパンジーの行動に酷似している.しかし，ハシボソガラスで見 られた行動がチンパンジーが他の個体をあざむく行動に表面的に酷似していたとしてす， これが偶然ではなく真性のフェイント行動であると断定するには，さらに観察例を重ねる 慎重さが必要だろう．たとえば，あとから飛来した他の個体の前を飛び去ったのは，単に 優位な個体を一時的に避けたためと解釈するような可能性を完全には否定できないからで ある。

他の地域での観察も含めて, 車利用行動についてさらに綿密な観察を蓄積することが何 より望まれるのである. 本論文は, ハシボソガラスの車利用行動に関する完全な定量的記 録を提出したあのというよりは，車利用行動の基本的変数とバリエーションの範囲を示し, これから検討されるべきいくつかの基本的な問題を指摘したものであるといえる.

この論文の概要は, 日本鳥学会津户基金シンポジウム「鳥の学習と文化」(1993 年 3 月, 立教大学) で報告した，桶口広芳，上田恵介，中村浩志，松村澄子，中村 司の各先生，黒沢令子さん，黒田治 男さん，ほ加日本野鳥の会の方々には，上記シンポジゥムで，またその後の論文執筆に際して有益な 助言や示唆をいただいた．また，車利用行動の研究と発表については，福島真一，林 重見の各氏， 嶋田一郎先生, 海野道郎先生, 鈴木孝男先生, 鹿野秀一先生には励ましや資料の教示をいただいた。 東北大学名誉教授相馬䙾吉先生や東北大学理学部附属植物園長遠田 宏先生にも, クルミの鑑定やク ルミについての知識を得る上でお世話になった，さらに，二人の医名レフェリーによる論文初稿への 綿密かつ慧切な指摘は，車利用行動の意味をさらに考え直す上で示唆に富むるのであった，なお，本 研究については，文部省科学研究補助金（課题番号 06801011）による援助を受けた。

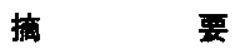

1）ハシボソガラスが自動車をクルミ割りに利用する行動について長期的な観察を行なった。

2）信号待ちで停車した自動車の車輪の前にクルミを置き，車がひいたクルミを摄食する事例が頻繁 に観察された．このことは，車利用行動が偶然なあのではなく意図的な行動であることを疑問の余 
地がなく示していた。

3）自動車利用によるクルミ割り行動は, 多くの変数（クルミの調達法，クルミの特性，クルミのセッ ティング方法, 時刻, 場所, 他の個体の存在, 待ち行動打ち切りの臨界時間, 㯰き直し行動, 食行 動）から構成されるバリエーションの多い行動であることが確認された.

4）自動車利用行動は，上空から投下する方法では割れないクルミを処理するための新たな手段とし て生まれたものであると考えられた。

\section{引用文献}

VAN LawiCK-Goodall, J. 1971. In the shadow of man. London: William Collins Sons \& Co Ltd. 河合雅雄訳 森の隣人 : チンバンジーと私 1973 東京 : 平凡社

Goodall, J. 1986. The Chimpanzees of Gonbe-Patterns of Behavior. Cambridge: Harvard University Press. 杉山幸丸・松沢哲郎監訳 野生チンパンジーの世界 1990 京都：ミネ ルヴァ萻房

Grobecker, D. B., and Pietsch, T. W. 1978. Crows use automobiles as nutcrackers. Auk $95: 760-761$.

Higuchl, H. 1986. Bait-fishing by the Green-backed Heron Ardeola striata in Japan. Ibis $128: 285-290$.

Higuchn, H. 1988. Individual differnces in bait-fishing by the Green-backed Heron Ardeola striata associated with the territory quality. Ibis $130: 39-44$.

科学技術庁資源調查会 (編)，1982. 四訂日本食品標準成分表 東京 : 大葴省印刷局

唐沢孝一, 1988. カラスはどれほど蜸いかー都市鳥の適応戦略一. 東京 : 岩波書店

小林挂助, 1983. 原色日本鳥類図鍳（新訂增補版）大阪 : 保育社

MAPLE, T. 1974. Do crows use automobiles as nutcrackers? Western Birds 5 : 97-98.

松沢哲郎, 1991. チンパンジー・マインド一心と認識の世界一. 東京 : 岩波晴店

NaKamura, H. and TABata, T. 1988. Why does the Broad-billed Roller Eurystomus orientalis bring strange objects to the nest? Jap. J. Ornithol. $36: 137-152$.

中村浩志, 田畑孝宏, 1990.フィッ゚ウソウの䊒の食物 Jap. J. Ornithol. $38: 131-139$.

化平義明, 1992. ハシボソガラスの車利用による胡桃割り行動. 日本動物行動学会第11回大会発表要 旨集, 36 .

Norman, D. A. 1982. Learning and memory. San Francisco : Freeman.

Rumelhart, D. E. \& Norman, D. A. 1978. Accretion, tuning, and restructuring: Three modes of learning. In J. W. CotTon and R. KlatzKy (Eds.), Semantic factors in cognition. Hillsdale, N. J. : Erlbaum.

滝之入新一, 1993. アメリカ・カリフォルニア州のカラス等の生態について Urban Birds, 10, 64-65.

内田清之助, 1969. 岡田要・内田清之助・内田亨監修 新日本動物図鑑（下）（p. 662「ハシボソガラ ス」と「ハシブトガラス」の項) 東京 : 北隆館

上田惠介・小林和夫, 1991. キジラミ類（同翅亜目: キジラミ上科）の甘蕗を吸蜜するメジロ Zosterops japonica. Jap. J. Ornithol. $39:$ 103-105.

上田恵介, 1991. モモ夕マナ Terminalia catappa L. の花外慗腺から吸渱する小笠原のメジロ Zosterops japonica. Jap. J. Ornithol. 39 : 105-107.

$\mathrm{Z}_{\mathrm{ACH}}$, R. 1978. Selection and dropping of whelks by Northwestern Crows. Behaviour 67 : 134-147.

$\mathrm{Z}_{\mathrm{ACH}}$, R. 1979. Shell dropping decision-making and optimal foraging in Northwestern Crows. Behaviour 68 : 106-117. 